Article received on $30^{\text {th }}$ October 2014 Article accepted on $17^{\text {th }}$ December 2014

UDC: $316.75: 78(091)$ 655.41:78(73)"19" 78.011.26"19"

\author{
Ricardo Nogueira de Castro Monteiro* \\ Universidade Anhembi Morumbi \\ Music Production Department \\ School of Arts, Architecture, Design and Fashion
}

\title{
THE FIRST WORLD WAR AND THE ASCENSION OF THE PHONOGRAPHIC INDUSTRY IN THE NEW WORLD
}

\begin{abstract}
The First World War years witnessed a radical and important change in the history of both music and the phonographic industry, gradually putting popular rather than classical music under the spotlight and moving the axis of entertainment music production across the Atlantic into the New World. It is no coincidence that the first jazz, the first samba and also the first tango-canción were all recorded and released in the same year, 1917 - in the twilight of the Great War. This article intends to shed light on this process, discussing the cultural and socioeconomic factors that determined it.
\end{abstract}

Keywords: musicology; semiotics; tango; jazz; samba; music history; First World War; comparative history

\section{Introduction}

The British historian Eric Hobsbawm regarded as the "Age of Empire" the period between 1875 and 1914, defined as "an era of unparalleled peace in the western world, which engendered an era of equally unparalleled world wars". ${ }^{1}$ The present article aims to examine such a period through an unusual perspective: the development of the cultural industry - specifically, the phonographic

\footnotetext{
*Author contact information: castromonteiro@anhembimorumbi.edu.br

${ }^{1}$ Eric Hobsbawm, The Age of Empire, London, Orion [Kindle Edition], 2010, location 244.
} 
industry - and its interrelations with the geopolitical, economic, aesthetical and sociological forces that shaped that time and ultimately determined some of the major trends to be followed by popular culture ever since.

To an observer who intends to follow the history of music throughout these last centuries, a very complex - and even enigmatic - shift seems to have taken place around the first decade of the $20^{\text {th }}$ century. Until that moment, classical Western music - or even more specifically, classical European music - occupied an unrivaled position of prestige, exerting a powerful influence on other forms of musical expression such as the musique legère and popular music. Nevertheless, in the first decades of the $20^{\text {th }}$ century, a dramatic change took place, gradually putting popular music rather than classical music under the spotlight and moving the geographic axis of entertainment music production across the Atlantic to the New World.

Although the history of the phonographic industry actually places its introductory chapters on the American continent with the invention of the phonograph by Thomas Edison in 1877, and the first labels like the Edison Phonograph Company (1888), the Columbia Phonograph (1888) and the United States Gramophone Company (1894), the business quickly spread through Europe, reaching the United Kingdom in 1897 through the UK Gramophone Company - a sister to the American-based United States Gramophone Company. Columbia was the next to settle in Europe, opening an office in Paris en 1895 and in London in 1900. Nonetheless, by the time all these American labels expanded to Europe, the first native continental phonographic empire had already been established by Carl Lindström in Berlin (1893), soon to be joined by Parlophone (1896), Odeon (1903), Beka (1903) and Okeh (1916). In 1896, in Paris, the Pathé brothers founded a second but no less important empire, which became later one of the most important entertainment companies in the world. Hence, it becomes clear that a steady and consistent phonographic market was already well established in Europe by the end of the first decade of the $20^{\text {th }}$ century.

Despite the significant interest and efforts of the Victor Talking Machine Company (1901), classical music was eclipsed by popular music in sales practically from the beginning of the phonographic industry. If one could argue that the young, democratic and republican American society would find it particularly difficult to empathize with the masterpieces of the old, aristocratic, monarchic and geographically distant Europe, this explanation could by no means be extended to the European audiences. Even so, a quick examination of the Cylindres Pathé 1900-1910 catalog reveals first a reasonable balance and later a growing disadvantage of operatic singers with respect to the chansoniers who performed in the most prestigious cabarets and music halls of the time, like the Alcazar, the Casino de Paris or the Eldorado. Slowly but steadily, the classics performed by 
interpreters such as Affre "de l'Opéra", A. Mai - identified as "Primo Violino del Teatro alla Scala" - Jane Mérey and Noté "de l'Opéra" were outnumbered by the hits of singers like Charlus, Féraudy, Fragson, Duparc and the ever more acclaimed Polin.

If the above-mentioned description can possibly shed some light on the gradual process of the ascension of local popular music with respect to classical music on the European phonographic market at the beginning of the last century, explaining the rise in popularity of New World music definitely demands much more effort from any researcher interested in that subject.

\section{Continuity}

One can trace back to the second half of the $18^{\text {th }}$ century the first traces of what can be called "orientalism" - a specific expression of a wider phenomenon traditionally identified as "exoticism". Works like Die Entführung aus dem Serail [The Abduction from the Seraglio] (1782) by Mozart reveal a caricatural representation of the Austrian Empire's declining neighbor and rival - the Ottoman Empire - reinforcing stereotypes of customs seen in the West as barbarian, like polygamy and slavery. Ralph P. Locke explains the upheaval of orientalism in the following terms:

In the 19th and early 20th centuries, with the decline of the Ottoman Empire, the Middle East became a prime target for the colonization efforts of the Western powers and, accordingly, a much-favored locale in which to set operas and other musical works. Various standard 'Middle Eastern' musical gestures were first established in the popular Le desert of the French composer Félicien David, who had lived in Egypt for two years, and were then exploited by other composers, such as Bizet (Les pêcheurs de perles), Verdi (Aida), Massenet (Thaïs) and Richard Strauss (Salome). This heavily imaginary 'Middle East' was also a favored setting for ballets ( $L a$ source, with music by Delibes and Minkus) and modern-dance works (e.g. by Ruth St Denis). Many successful works were also set in East Asia, notably Puccini's Madama Butterfly and Turandot. ${ }^{2}$

Thus, the ascension of orientalism as a whole can be explained not only by the authentic interest in the aesthetic production of foreign nations - which was certainly the case for most of the artists involved in it - but also by its political usage, affirming the superiority of Western civilization during the age of Empire as a means of legitimating colonialism either by depicting the marvels of "the jewels of the Crown" (i.e. the colonies) as a form of reinforcing the prestige of

\footnotetext{
${ }^{2}$ Ralph P. Locke, “Orientalism”, In: Grove Music Online, Oxford Music Online, Oxford University Press, from http://www.oxfordmusiconline.com/subscriber/article/grove/music/ 40604, acc. 25 August 2014.
} 
the metropolis, or by ridiculing their "barbarian" customs. On the other hand, nationalism arguably capitalized from the popularity of exoticism to promote the interest of rising young nations or new powers from Russia to the Americas, assuming some aesthetic procedures foreign to the European traditional standards as components of their national identities. Debussy's considerations on how he benefited from his contact with the "exoticism" of Eastern Asian music, as much as his opinion on how Albéniz successfully expressed Spanish identity, appear in the article about the French composer signed by François Lesure and Roy Howat in the prestigious Grove Encyclopedia:

It was at the precise moment when he first turned his back on Wagner that Debussy discovered the music of East Asia at the 1889 Exposition. For him the revelation was far removed from the attraction of the exotic or the picturesque that it meant for many French composers, and concerned essentially the use of musical scales obeying conventions other than those of the West. He listened spellbound to the 'infinite arabesque' of the Javanese gamelan with its percussion - the Western equivalent of which he likened to the 'barbaric din of a fairground' - and the counterpoint 'beside which Palestrina's is child's play', and he was equally fascinated by the Annamite theatre, which impressed him by its economy of means: 'an angry little clarinet' and a tam-tam. He himself never introduced any form of unmediated exoticism into his music, except arguably into Pagodes, but the gamelan has been suggested as one influence in the Fantaisie for piano and orchestra, and in the Toccata of the suite Pour le piano, composed shortly after the 1900 Exposition. Debussy was always consistent on the point that a folk or national music should not be used for its themes but rather in the manner of Albéniz: 'Without using actual popular tunes he is the kind of person who has them in his blood. They have become so natural a part of his music that one barely distinguishes a demarcation line'. ${ }^{3}$

Quite different from such a positive description - and closer to an allegory of colonialism - are songs like La Petite Tonkinoise, a hit written in 1905-1906 by the successful popular composer Vincent Scotto with lyrics by Georges Villard and Henri Christiné. The enunciator of the song is not really concerned with learning something as basic as the name of his lover, a native woman from Tonkin - a region that belonged to the former French colony of Indochina, in present day Vietnam. He simply calls her "ma p'tite bourgeoise, ma Tonkiki, ma Tonkiki, ma Tonkinoise". The song starts insinuating that she might not be his only affair, saying "Y en a d'autres qui m' font les doux yeux, mais c'est elle que j'aime le mieux" [there are others that bring sweetness to my eyes, but she is my favorite one]. Some metaphors of dubious taste present the male enunciator exploring her body as if he were learning geography - not surprisingly,

\footnotetext{
${ }^{3}$ François Lesure and Roy Howat, "Debussy, Claude", In: Grove Music Online, Oxford Music Online, Oxford University Press, from http://www.oxfordmusiconline.com/subscriber/ article/grove/music/07353, acc. 25 August 2014.
} 
often alluding to the domains of the Asiatic colonies - with images as crude as "l'Amour, c'est curieux, qu'arrose l'Empire du Milieu" [love, how intriguing, irrigates the Middle Kingdom]. Ironic remarks abound, like mentioning that, as the daughter of a powerful mandarin, she had on her chest two small mandarins, making it difficult to believe in the sincerity of the enunciator despite his claims that his heart was full of sadness at bidding her goodbye - but never considering the possibilities of marrying her or taking her back to France with him.

In this complex context that combined in the Belle Époque the apparent cynicism of La Petite Tonkinoise with the reverence of artists like Debussy and the last echoes of nationalism, the music of the New World slowly started to be heard in the Parisian saloons. Pierre Saka affirms in his La chanson française: des origines à nos jours [The French Song: From the Origins till Our Days] that the year of 1902 would mark the arrival of North American music in Paris with the boom of the Cakewalk music and dance ${ }^{4}$ - a novelty that maybe Parisians had already been introduced to thanks to John Philip Sousa's successful concerts in the 1900 "Grande Exposition". Affirming that the Cakewalk was "the first American dance to cross over from black to white society as well as from the stage to the ballroom", Claude Conyers identifies its origins in a "contest for performers walking solemnly while balancing buckets of water on their heads" that "seems to have been a parody of the elegant manners and fancy dances of white slaveholders" in Florida in the middle of the $19^{\text {th }}$ century, and which ordinarily offered a piece of cake as a prize - thus, the origin of its name. Surviving the end of the slavery era, the cakewalk reached the 1890 s as a popular dance, and "“cakewalk contests' among dancing couples were being organized as public entertainments in many northern American cities" around that time. ${ }^{5}$ Reaching France, the dance becomes extremely popular and soon develops a local repertoire, including hits like Américain noir by Félix Mortreuil and Émile Spencer, where a female enunciator is infatuated with a man who "par sa danse nègre il me charme" [a man who has captivated me with his negro dancing]. Other songs had a far more contemptuous attitude towards the exoticism of the new fashion, like Le cake-walk-irie, by E. Sérard and F. Chaudoir, whose lyrics describe that "dans la France, chacun danse en cadence et furie; c'est stupide, insipide, c'est de la cake-walk-irie" [in France, everyone is furiously dancing that cadence; it's stupid, tasteless, it's the cake-walk-irie].

${ }^{4}$ Pierre Saka, La Chanson Française: Des Origines à Nos Jours [The French Sonf: From the Origins till our Days \}, Paris, Éditions Fernand Nathan, 1983, p. 95.

5 Claude Conyers, "Cakewalk", In: Grove Music Online, Oxford Music Online, Oxford University Press, from http://www.oxfordmusiconline.com/subscriber/article/grove/music/ A2092374, acc. 25 August 2014. 
Nonetheless, the Cakewalk in particular, or even American music in general, was not the only New World musical expression that was booming in Paris in the pre-war era. A far more important cultural phenomenon both with its historical relevance and its complexity would take place with the vertiginous ascension of the Argentinian tango. If a young student in the $21^{\text {st }}$ century might be surprised with the boom of a South American style and its prestige in the old, powerful and rich Europe of the early $20^{\text {th }}$ century, a well-informed observer from that time would hardly feel amazed at it. Meantime, dramatically shaken by an economic crisis that had been ruining its finances for more than 20 years, Argentina in the early 1900 s was one of the 10 wealthiest countries in the world. ${ }^{6}$ According to Harvard Economics Professor Edward Glaeser, "in 1909, the per capita income in Argentina was 50\% higher than in Italy, 180\% higher than in Japan, and almost five times higher than in neighboring Brazil".?

If this data can partly explain the prestige Argentina could claim in European eyes, still it could not respond to its widespread presence in the French capital. Horacio Salas sheds some light on this phenomenon, pointing to a longstanding Francophile tradition among the Argentinian elite, who cultivated the custom of sending their sons to Paris in order to complete their education and enrich their intellectual horizons. ${ }^{8}$ A more thorough analysis of the meaning and importance of the presence of the Argentinian elite in Paris is offered by Andrés Carretero in his Tango: testigo social [Tango: a Social Witness]. According to Carretero, the same elite that was deaf to the aspirations of the less favored classes, used to travel to Europe in the Belle Époque to flaunt their wealth, joining a small social segment whose lifestyle was as expensive as hedonistic. Thus, the sons of the Argentinian elite would believe that their money and lavish spending could grant them culture, refinement, beauty and social distinction. ${ }^{9}$ Actually, their behavior did impress French society - but not exactly in the most positive way. A French neologism, rastaquouère, originated from the Spanish rastacuero (literally, "leather dragger", alluding to the ostentation of fortune earned by cattle-raising)

\footnotetext{
${ }^{6}$ Ana I. Eiras and Brett D. Schaefer, Argentina's Economic Crisis: An "Absence of Capitalism", In: The Heritage Foundation - Backgrounder, 2001, no.1432, from http://www. heritage.org/research/reports/2001/04/argentinas-economic-crisis-an-absence-of-capitalism, acc. 25 August 2014.

${ }^{7}$ Edward L. Glaeser, "What Happened to Argentina?", In: The New York Times, 6 October 2009, Economix, from http://economix.blogs.nytimes.com/2009/10/06/what-happened-toargentina/?_php=true\&_type $=$ blogs\&_r=0, acc. 25 August 2014.

${ }^{8}$ Horacio Salas, El Tango [The Tango], Buenos Aires, Emecé, 2004, p. 114.

${ }^{9}$ Andrés M. Carretero, Tango: Testigo Social [Tango: a Social Witness], Buenos Aires, Ediciones Continente, 1999, p. 78.
} 
indicated an exotic character that lived a luxurious life but had rather dubious taste, or even, according to the prestigious French dictionary Le Nouveau Petit Robert, "whose fortune might have a suspicious origin". ${ }^{10}$

Thus, admired or disdained, a small but significant part of the Argentinian elite used to sojourn in Paris during the Belle Époque. But it was not the cattleraising aristocracy that was to leave a long-lasting mark in Western culture, but the predominantly lower or middle class tango geniuses that began to flood into the city during that period. According to Luis Labraña and Ana Sebastián in their Tango: una historia [Tango: A History], a pioneering Argentinian group of tango authors arrived in Paris as early as 1903, including the successful author of the classic El Choclo, Ángel Villoldo, and other names like Enrique Saborido, Alfredo Gobbi and his wife, the Chilean singer Flora Rodríguez. ${ }^{11}$ Salas slightly contradicts - or maybe just develops in greater detail - this affirmation, claiming that the previously mentioned couple and Villoldo would have reached Paris in 1907, and that Gobbi and Rodríguez would have spent about seven years in the French capital, composing, giving tango dance lessons and producing recordings registered by the Pathé Brothers. ${ }^{12}$

\section{Friction}

The spread of the tango, in Paris, and worldwide, did not take place without resistance. But its rejection - just as the rejection of jazz and the samba - actually represents a key social and cultural phenomenon to understand its ascension in the First World War period. The balance of forces was changing, the conservative trends on one side, with a strong prejudice against those new styles rooted in the basis of the social pyramid, and on the other side the aesthetic and cultural transformations related to accepting and absorbing the rising classes and their respective values. Nicolás Slonimsky displays in his La música de América Latina [Latin American Music] an interesting - and sometimes even funny - collection of critics among remarkable personalities from both the European and the American continent who were against the tango and its fashion:

In his message of January 1, 1914, the Archbishop of Paris threatened Tango addicts with excommunication: 'We condemn the dance of foreign origin known as the Tango, which by its lascivious nature offends morality. Christians ought not in con-

\footnotetext{
${ }^{10}$ Paul Robert, Le Nouveau Petit Robert \{The Hew Petit Robert], Paris, Dictionnaires Le Robert, 1994, pp. 1870-1871.

${ }^{11}$ Luis Labraña \& Ana Sebastián, Tango: Una Historia [Tango: A History], Buenos Aires, Corregidor, 2000, p.43.

${ }^{12}$ Horacio Salas, op. cit., p. 116.
} 
science to take part in it. Confessors must in the administration of the sacrament of penance enforce these orders.' Cardinal O'Connell of Boston declared: 'If this Tango-dancing female is the new woman, then God spare us from any further development of an abnormal creature.' To vindicate the honor of his country, the Ambassador of Argentina in Paris was compelled to state formally that the Tango was 'a dance peculiar to the houses of ill repute in Buenos Aires, and is never cultivated at respectable gatherings'. ${ }^{13}$

The Ambassador's phrase is another most important point to be considered, for it openly expresses how despised the tango was by the Argentinian elites in Buenos Aires, and how surprised the "rastacueros" were to see it acclaimed in the most exclusive and prestigious Parisian addresses. Hélio Fernandes reinforces in his Tango: uma possibilidade infinita [Tango: An Infinite Possibility] that the triumph in Paris was instrumental to a complete change of attitude from the Argentinian elites with respect to the tango, from total rejection to absolute consecration, and finally pride as an authentic national symbol of identity. Fernandes quotes the Buenos Aires magazine El Hogar [The Home], that writes in 1911 that "the aristocratic halls of the great capital have welcomed with enthusiasm a gender which, here, due to its filthy tradition, is not even mentioned at our balls [...]. Will Paris ultimately make our good society accept the Argentinian tango?"14

Yes, it really did. And this fact had capital importance not only for the further national and international development of the tango, but also for the acceptance of some Brazilian genres in Brazil. As Glaeser points out in his article, the Brazilian giant's southern neighbor was in that time five times as rich as Brazil, despite being approximately one third of the size of Brazil. Buenos Aires in 1930 still had a population that was approximately $28 \%$ larger than Rio de Janeiro's, ${ }^{15}$ at that time the capital and largest city of Brazil, and it was a far more prestigious cultural center. Rio de Janeiro was a necessary stop for most ships heading to Buenos Aires - and also to most ships leaving the Argentinian capital - which favored an intense cultural communication between the two cities. For that reason, Brazil's most prominent composer of the national style called "choro" classified his compositions as "Brazilian Tangos" instead of using the proper - but less prestigious - term to define their genre. Choro (mainly instrumental) and Samba

\footnotetext{
${ }^{13}$ Nicolás Slonimsky, La Música de América Latina [Latin American Music], Buenos Aires, El Ateneo, 1947, p. 26.

${ }^{14}$ Hélio de Almeida Fernandes, Tango: Uma Possibilidade Infinita [Tango: An Infinite Possibility], Rio de Janeiro, Bom Texto, 2000, p. 69.

${ }^{15}$ Olivier Dabène, América Latina no Século XX [Latin America in the 20th Century], Porto Alegre, EDIPUCRS, 2003, p. 30.
} 
(a song style) are musically deeply related, and not surprisingly the rise of the first preceded the breakthrough of the second in 1917.

Aesthetically conservative forces in the Americas were often hostile to local musical expressions, identifying themselves with a culture and values purported to be European - in fact were only a fragile discourse of the elites to try to legitimate social inequality with an alleged, ethnic distance with respect to the majority of the population, who were invariably supposed to be more miscegenated, and revealed the top classes' constant tendency to empathize with interests foreign to the nation as a whole but beneficial to their own social group or part of it. This problem was not an exclusively Latin American issue. It is again Slonimsky who collects some invaluable quotes about an analogous phenomenon regarding resistance to American music. Among the European voices that rose against Jazz, he highlights Maxim Gorky and Cyril Scott. The great Russian writer described his impressions of jazz in the following words: "Listening to this screaming music for a minute or two, one conjures up an orchestra of madmen, sexual maniacs, led by a man-stallion beating time with an enormous phallus". No less exaggerated is the caricatural view by the English composer and theosophist Cyril Scott: "After the dissemination of jazz, which was definitely put through by the Dark Forces, a very marked decline in sexual morals became noticeable. Whereas at one time women were content with decorous flirtation, a vast number of them are now constantly preoccupied with the search for erotic adventures, and have thus turned sexual passion into a species of hobby". ${ }^{16}$ The critics in America were no less fierce or passionate, as can be read in the following passage:

The custodians of public morals were profoundly shocked by the rise of syncopated music in America at the turn of the century. The Musical Courier, in an editorial entitled 'Degenerate Music,' published in its issue of September 13, 1899, took note of the new peril: 'A wave of vulgar, filthy and suggestive music has inundated the land. Nothing but ragtime prevails, and the cake-walk with its obscene posturings, its lewd gestures.... Our children, our young men and women, are continually exposed to the contiguity, to the monotonous attrition of this vulgarizing music. It is artistically and morally depressing, and should be suppressed by press and pulpit'. ${ }^{17}$

The objections against these forms of the expression of popular music often choose arguments based upon physical and/or moral repulsion. The mottos of obscenity, treated both as a social and religious issue, as much as animality and filthiness, among other isotopies, reinforce the reading of physical and/or cultural miscegenation as negative values, coherently with the infamous Eugenist

\footnotetext{
${ }^{16}$ Nicolás Slonimsky, op. cit., pp. 24-26.

${ }^{17}$ Ibid.
} 
theories which were growing in popularity among the ruling classes of the period. Another important invariance consists of a common feature of these three so different musical genres: the syncope. The entry for "syncopation" in the prestigious Grove, the largest music encyclopedia in the world, reads:

The regular shifting of each beat in a measured pattern by the same amount ahead of or behind its normal position in that pattern [...] Because any syncopated musical line can be perceived as contrary to the pulse established by the organization of the music into bars, syncopation is related to, and sometimes used as a synonym for, cross-accent, agogic accent and cross-rhythm [...] A texture in which every part conflicts with the sense of the prevailing metre, or even overcomes it, is also called syncopated...

Let us bear in mind here not only a musical procedure as "to vary position of the stress on notes so as to avoid regular rhythm", as defined in The Oxford Dictionary of Music, but also the semiotic chain of meanings related to that definition. It is fundamental here to have in mind that syncopation is "contrary" to the prevailing "organization", and that it essentially "conflicts with" "or even overcomes" it. With these ideas in mind, would it be defensible to recognize in syncopation a metaphor or a gesture connoting some kind of subversion or social rebellion? Even if one considers the fact that this was quite a common musical procedure both in the Maghreb and in the Sub-Saharan area, the African-American syncopation in North as in South America takes place in a multicultural context where European aesthetic patterns stand as the "rule", the syncope being a structural procedure in the new popular music whereas it appears as an occasional resource in the European reference repertoire. Figures 01 to 04 display the omnipresence of syncope in such different styles as the cakewalk, tango, samba and early jazz.

Fig. 01 - Syncopes in Cake-walk, composition by Kerry Mills published in L'Illustration in 1903

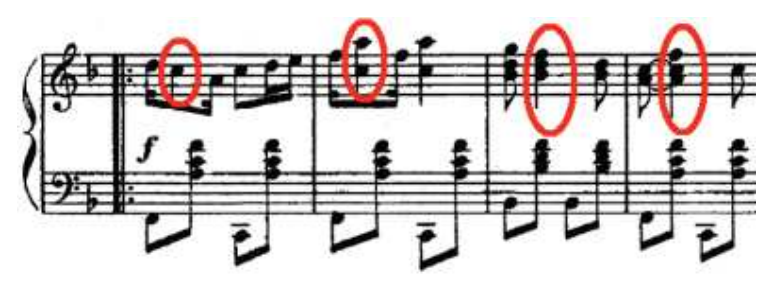

Fig. 02 - Syncopes in Mi noche triste, tango by Samuel Castriota recorded by Carlos Gardel in 1917, considered the first tango-canción [song tango] recording

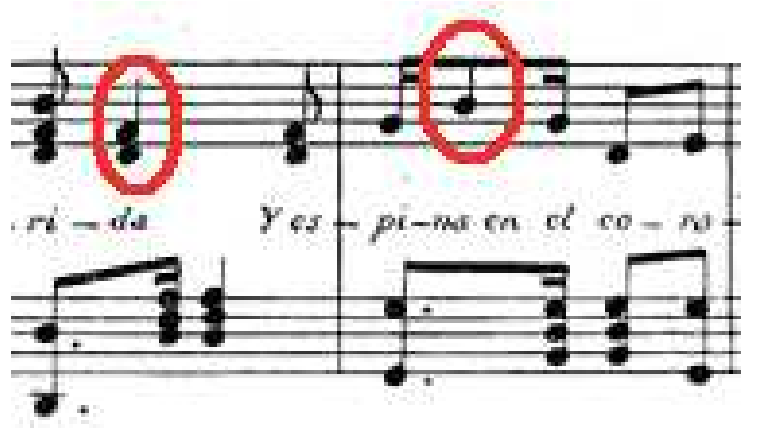


Fig. 03 - Syncopes in Pelo telefone, samba recorded by Donga in 1917, considered the first samba recording

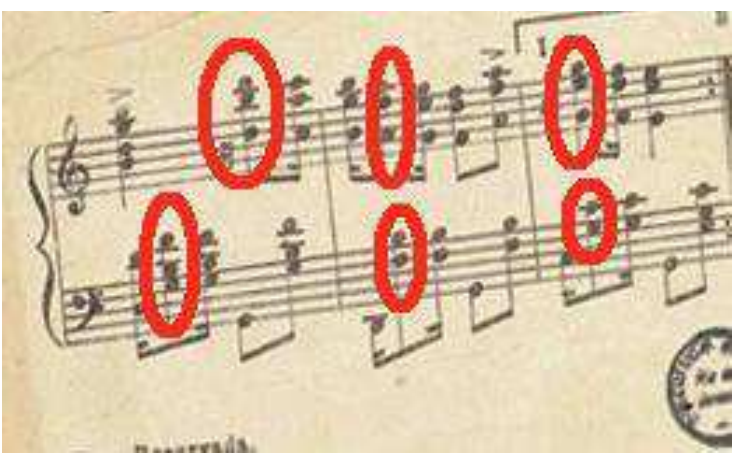

Fig. 04 - Syncopes in Livery Stable Blues, recorded by the Original Dixieland Jass Band in 1917, considered the first jazz recording

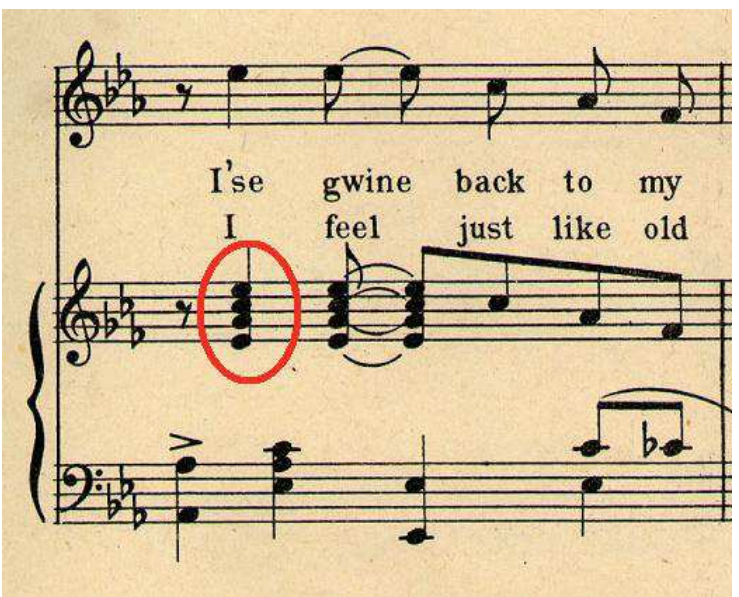

Anyway, despite fierce social and racial prejudice, in the United States as in Brazil and Argentina, an ascending middle class, not exclusively but at least partially constituted of descendants of former African slaves, did empathize with the mixed-African new styles as a component of their sense of social identity. At the same time, as described above, the tango and cakewalk in Europe were becoming increasingly popular. Nonetheless, the resistance against the above mentioned genres of popular music would undergo a radical change at the beginning of the First World War, as it will be examined in the following item.

\section{Discontinuity}

While the First World War had a terrible impact on the European phonographic industry, its consequences in the Americas were extremely complex. If, on the one hand, it jeopardized both the productive chain and sales, on the other, it not only knocked the European competitors practically out of the market for some years but also created a vacuum in terms of artistic production that the New World labels and artists promptly struggled to occupy. In his Cowboys and Indies: The Epic History of the Record Industry, Gareth Murphy informs us that one year after the outbreak of the war, Victor Talking Machine had reached its first million-unit record and by 1917, the year the United States joined the war, Victor had sold one million victrolas and released about 7,000 titles. ${ }^{18}$ Even Carl Lind-

${ }^{18}$ Gareth Murphy, Cowboys and Indies: The Epic History of the Record Industry, New York, Thomas Dunne Books, 2014, p. 26. 
stron's European-based phonographic empire greatly benefitted from an expansion to the American continent, intelligently organized in the years immediately before the war. The opening of the Odeon factory in Rio de Janeiro in 1913 made it viable to produce and distribute Lindstron's records during the eclipse of the European production, allowing the German group to witness and profit from the expansion of the South American market through Brazil, Argentina and Uruguay while its original market in the Berlin headquarters became practically non-existent. ${ }^{19}$ Nevertheless, the impact of the war on the phonographic industry would by far transcend the limits of logistic and market issues. The trend to improve the balance in gender relations gained momentum when the war effort in Great Britain started to absorb as much female labor as possible in the factories, since the majority of the male work force were at the Front. With a massive contingent of women working outside their homes and making their living independently with their own resources, it is no wonder that between 1913 and 1920 women conquered the right to vote in countries like the United Kingdom, the United States, Germany, Holland, Russia, Poland, Denmark, Norway and Australia. Meanwhile, in the United States, the war effort accentuated the so-called Great Migration, whereby a significant section of the African-American population would migrate from the Southern plantations and cities towards the North and Northeast to join their industrial boom, occupying in particular neighborhoods such as Harlem in New York City, and Chicago, and Illinois. There, according to Murphy:

All these migrations and upheavals in black and female culture explain why suddenly in 1917, the year America joined the war, a new dance craze exploded in Chicago and New York - jazz, the first organically grown musical wave to rise from the street and change the face of the record business. ${ }^{20}$

Nevertheless, the launching of the Livery Stable Blues by the Original Dixieland Jass Band in 1917, considered the first jazz ever to be recorded, cannot be analyzed in depth if regarded as an exclusively American phenomenon. After all, the phonographic industry requires a vivid counterpoint with popular culture, echoing or fabricating trends and "musical waves" that reflect the values and beliefs of a society as a whole or of some of its margin groups. Franceschi observes that the war years coincided with the ascendence of the American influence upon Brazilian culture and consumer habits, with a significant burst of popularity of genders such as the Charleston and fox-trot. ${ }^{21}$ Such a scenario would easily sug-

\footnotetext{
${ }^{19}$ Humberto Franceschi, A Casa Edison e Seu Tempo [Casa Edison and its Time], Rio de Janeiro, Biscoito Fino, 2002, p. 188.

${ }^{20}$ Gareth Murphy, op. cit., p. 32.

${ }^{21}$ Humberto Franceschi, op. cit.
} 
gest a simple change of axis from European to North American cultural predominance in countries, such as Brazil and Argentina.

The reasons why such a shift did not take place at that moment are both complex and varied. First, before the radio age, local traditions were still far more resistant to foreign influences than they would later become - and it is important to bear in mind that the tango had been heard in Argentina since at least the 1850s, and genres related to the samba can be traced back in Brazil as early as the late $18^{\text {th }}$ century. Secondly, at the beginning of the war, the tango had already consistently succeeded in conquering hearts and minds on both sides of the Atlantic, whereas the golden years of American music were still to appear on the horizon. Thirdly, the United States would enter the war in 1917, which led to the Victor factories, for example, being partly used to manufacture rifle parts and biplane wings, and reducing its production by $40 \%$, to only 21 million discs in $1918^{22}$ and consequently producing an invaluable opportunity to the modern and rapidly expanding phonographic industry in South America. Evaldo Piccino observes that the international catalogue of phonograms by Casa Edison, the Brazilian company that owned the Odeon rights in Brazil during the war years, was understandably dominated by Argentinian rather than by European or American titles - but also that international titles were becoming vastly outnumbered by the local Brazilian recordings. ${ }^{23}$ Argentina, in the splendor of its glorious years, as one of the largest economies in the world, now exporting a tango culture that was revered in Paris, New York, Tokyo, Rio de Janeiro and worldwide, was therefore far from being tempted to succumb to American cultural domination. Brazil, without the Argentinian glamour and GDP, was then, on the other hand, the headquarters of the phonographic industry in South America. Not surprisingly, not long after the crisis of the phonographic industry finally reached Brazil, the first samba was recorded by Donga in 1917, starting a process intentionally or not, which was analoguous to those that in Argentina and the United States resulted both in the vigorous expansion of the local market and an everlasting mark on popular culture.

Thus, the First World War was instrumental to the ascendence of the New World's Music in the phonographic industry not only due to the collapse of European recording production, but also because it indirectly triggered a chain socioeconomic reaction that has greatly contributed to the local cultural production

${ }^{22}$ Gareth Murphy, op. cit., p. 26.

${ }^{23}$ Evaldo Piccino, "Um Breve Histórico dos Suportes Sonoros Analógicos: Surgimento, Evolução e os Principais Elementos de Impacto Tecnológico" [A Brief History of Analogic Sound Supports: Origins, Evolution an the Most Important Factors of Technological Impact], In: Revista Sonora [Sound Magazine], Vol. 1, No. 2 (1), 2003. 
on the American continent ever since. As a result of that process, by the end of the war, the New World's music had gained sufficient momentum, from that moment on, to rival European phonographic production on the international market worldwide, and even the European market itself - an almost unthinkable situation at the dawn of the phonographic industry's history.

\section{References}

Carretero, Andrés M., Tango: Testigo Social, Buenos Aires, Ediciones Continente, 1999

Conyers, Claude, "Cakewalk", In: Grove Music Online, Oxford Music Online. Oxford University Press, from http://www.oxfordmusiconline.com/subscriber/article/grove/ music/A2092374, acc. 25 August 2014.

Cooke, Deryck, The Language of Music, London, Oxford University Press, 1959.

Dabène, Olivier, América Latina no Século XX, Porto Alegre, EDIPUCRS, 2003.

Eiras, Ana I. \& Schaefer, Brett D., “Argentina's Economic Crisis: An 'Absence of Capitalism", In: The Heritage Foundation: Backgrounder, 2001, no.1432, from http://www. heritage.org/research/reports/2001/04/argentinas-economic-crisis-an-absence-of-capitalism, acc. 25 August 2014.

Fernandes, Hélio de Almeida, Tango: Uma Possibilidade Infinita, Rio de Janeiro, Bom Texto, 2000.

Franceschi, Humberto, A Casa Edison e Seu Tempo, Rio de Janeiro, Biscoito Fino, 2002.

Glaeser, Edward L., "What Happened to Argentina?", In: The New York Times: Economix, 6 October 2009, from http://economix.blogs.nytimes.com/2009/10/06/what-happenedto-argentina/? php=true\&_type=blogs\&_r=0, acc. 25 August 2014.

Hobsbawm, Eric, The Age of Empire, London, Orion [Kindle Edition], 2010, location 244

Labraña, Luis \& Sebastián, Ana, Tango: Una Historia, Buenos Aires, Corregidor, 2000.

Lesure, François \& Howat, Roy, "Debussy, Claude", In: Grove Music Online, Oxford Music

Online, Oxford University Press, from http://www.oxfordmusiconline.com/subscriber/article/grove/music/07353, acc. 25 August 2014.

Locke, Ralph P., "Orientalism”, In: Grove Music Online, Oxford Music Online, Oxford University Press, from http://www.oxfordmusiconline.com/subscriber/article/grove/ music/40604, acc. 25 August 2014.

.’Exoticism", In: Grove Music Online, Oxford Music Online, Oxford University Press, from http://www.oxfordmusiconline.com/subscriber/article/grove/music/45644, acc. 25 August 2014.

Murphy, Gareth, Cowboys and Indies: The Epic History of the Record Industry, New York, Thomas Dunne Books, 2014.

Piccino, Evaldo, Um Breve Histórico dos Suportes Sonoros Analógicos: Surgimento, Evolução e os Principais Elementos de Impacto Tecnológico, In: Revista Sonora, Vol. 1, No. 2 (1). 2003.

Robert, Paul, Le Nouveau Petit Robert, Paris, Dictionnaires Le Robert, 1994. 
Saka, Pierre, La Chanson Française: Des Origines à Nos Jours, Paris, Éditions Fernand Nathan, 1983.

Salas, Horacio, El Tango, Buenos Aires, Emecé, 2004.

Slonimsky, Nicolás, La Música de América Latina, Buenos Aires, El Ateneo, 1947.

"Syncopation", In: Grove Music Online, Oxford Music Online, Oxford University Press, from http://www.oxfordmusiconline.com/subscriber/article/grove/music/27263, acc. 29 August 2014.

"Syncopation", In: The Oxford Dictionary of Music, 2nd ed. rev., Oxford Music Online, Oxford University Press, from http://www.oxfordmusiconline.com/subscriber/article/ opr/t237/e10023 acc. 29 August 2014. 